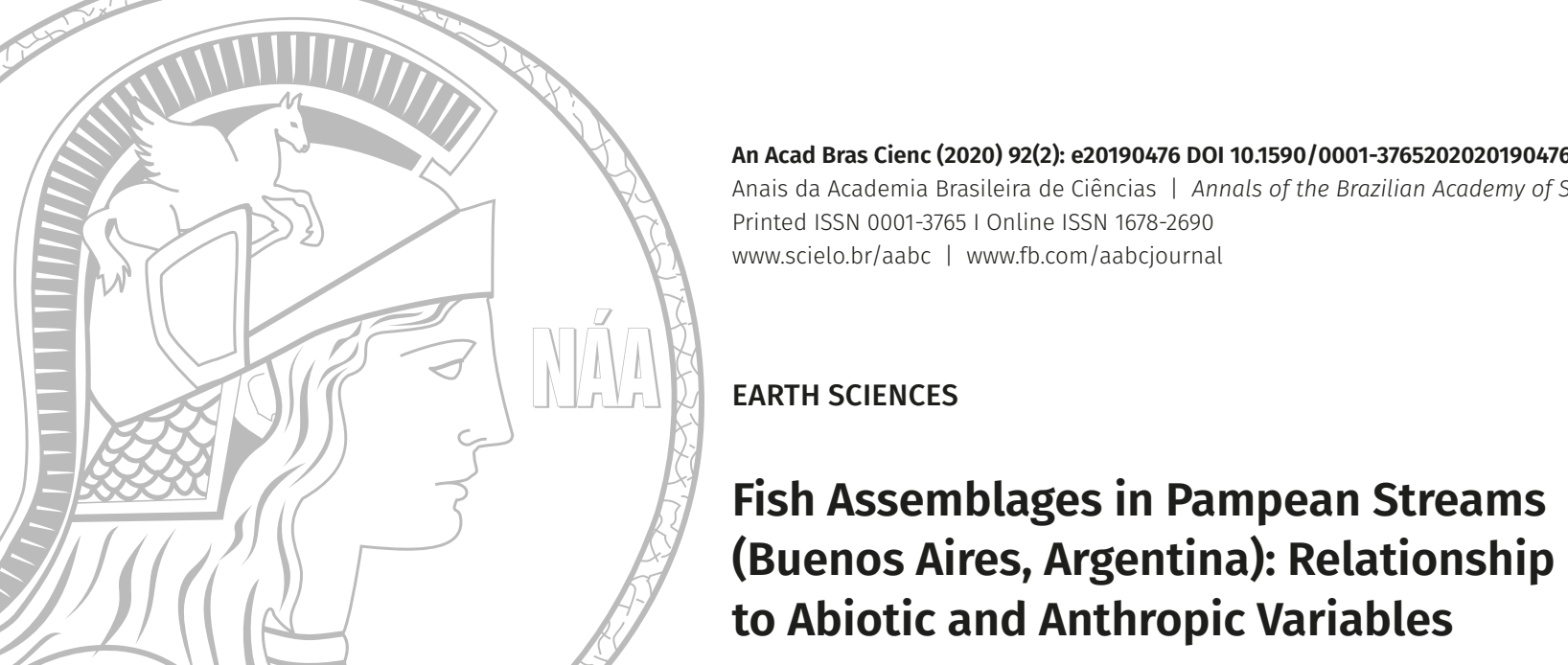

\title{
Fish Assemblages in Pampean Streams (Buenos Aires, Argentina): Relationship to Abiotic and Anthropic Variables
}

\author{
ARIEL PARACAMPO, NATALIA MARROCHI, IGNACIO GARCÍA, TOMÁS MAIZTEGUI, \\ PEDRO CARRIQUIRIBORDE, CARLOS BONETTO \& HERNÁN MUGNI
}

\begin{abstract}
The present study reported the effect of natural and anthropic environmental variables on the fish assemblages in the pampean streams, in the coastal strip along the Río de la Plata, Buenos Aires province, Argentina. Five streams were sampled at 12 sites surrounded by land devoted to different uses. A correspondence analysis sorted the streams into two groups: a less impacted group formed by sites surrounded by livestock- raising pastures and a more impacted one passing through urban sites and including a stream adjacent to a modest rural urbanization with a dairy in the stream's basin. The nutrient concentrations were significantly higher in the more impacted group; with species richness, diversity, abundance, and biomass being significantly lower. A canonical-correspondence analysis linked the more impacted sites to high concentrations of soluble reactive phosphorus and impoverished fish assemblages, composed of species tolerant to environmental pollution. On the other hand, sites with higher oxygen concentrations and $\mathrm{pH}$ were related to richer assemblages pointing to good environmental conditions at the sites surrounded by livestock-raising pastures. The downstream sites on the less impacted streams contained fish assemblages in which the juvenile stages of species corresponding to the Río de la Plata were dominant.
\end{abstract}

Key words: environmental variables, freshwater fish, land use, nutrient concentrations.

\section{INTRODUCTION}

Water quality in streams is strongly dependent on the surrounding terrestrial environment (Wallace et al. 1999, Pinto et al. 2006). Changes in land use are the most expected source of alterations in stream biodiversity (Sala et al. 2000). The principal modifications include increased agriculture, horticulture, urban and industrial development. More than $68 \%$ of the world's population will live in urban areas by the year 2050 (UN DESA 2018). The effects of urbanization involve increased concentrations of nutrients, metals, and pesticides plus erratic hydrology, channelization, and bank destabilization (Paul \& Meyer 2001, Allan 2004). Streams draining urban basins have often exhibited low richness and diversity of the fish species (Klein 1979, Helms et al. 2009), low biomass, and the absence of pollution-sensitive species (Lenat \& Crawford 1994, Oronato et al. 2000). The number of invasive species was observed to increase (Boet et al. 1999), whereas the biotic integrity was found to decrease in urban basins (Steedman 1988, Wang et al. 1997, Yoder et al. 1999).

Several references involving the effect of land use on fish assemblages refer to Holartic fauna, whereas the Neotropical region-it has the most diversified freshwater-fish fauna in the world (Lévêque et al. 2008)-remains largely unreported (Cunico et al. 2006). The 
pampas region around the city of Buenos Aires, Argentina, contains a high population density and degree of urbanization (Herrero et al. 2009). The streams of that region often receive runoff from industrial and household sources, with a consequent deterioration in water quality (Padulles et al. 2017). The composition of the fish assemblages in a few pampean streams has been reported by Di Marzio et al. (2003), Remes Lenicov et al. (2005), Fernández et al. (2008), Colautti et al. (2009) and Granitto et al. (2016). A comprehensive assessment on a larger scale of the relationship between community structure and environmental variables, however, remains unreported. Under natural conditions, the structure and the composition of fish assemblages respond more to variations on a local scale-i. e., the distance from sources, the basin area, and the stream order and widththan on a regional scale (ecoregion; TejerinaGarro et al. 2005). Those authors underscored the necessity to identify natural and human effects on assemblage compositions in order to develop more comprehensive conservationmanagement policies.

Fish are useful organisms for assessing environmental degradation because many species are sensitive to different types of disturbances and can reflect the adverse effects on the habitat modifications. Fish thus, represent an appropriate tool for diagnosing anthropic impact on their environment (Karr 1981).

Within this context, the aim of this study was to assess fish assemblages in pampean streams and to determine their structure in relation to natural versus anthropically impacted environmental variables. Our hypothesis was that urbanization would produce assemblages of lower abundance and diversity along with a predominance of a few tolerant species.

\section{MATERIALS AND METHODS}

\section{Study sites}

Five streams were sampled between January 2009 and March 2011 at 12 separate sites surrounded by different types of land use. The streams studied are located at the Río de la Plata coastal fringe, around the cities of La Plata and Magdalena, Buenos Aires province, Argentina (Fig. 1)

The Rodríguez Stream drains an urbanized basin in the area around the city of La Plata. The Pescado Stream was sampled at sites surrounded by fields devoted to extensive livestock raising. The Zapata Stream drains a heterogeneous basin of multiple land uses, but mainly livestock. A small rural urbanization, General Mansilla, containing 2,000 inhabitants and a dairy, however, are also located in the upstream area of the basin (Fig. 1). The Buñirigo Stream drains an extensive livestock basin. At the southernmost sampling site, close to the mouth of the stream, two industrial establishments are located, a food-production plant and a tannery. The Juan Blanco Stream drains an extensive homogeneous livestockcontaining basin. Livestock-raising throughout the whole area involves cattle at low densities grazing on pastures.

The climate is mild and humid with mean monthly temperatures ranging from $9.9^{\circ} \mathrm{C}$ in July to $22.4{ }^{\circ} \mathrm{C}$ in January. The mean annual precipitation is $1,060 \mathrm{~mm}$ featuring small seasonal variations (Hurtado et al. 2006). All the streams under study drain the eastern part of the pampas plain, it has a small regional slope. The streams have low water flow, silt bottoms, and a high suspended-matter content (Rodrigues Capitulo et al. 2010). As there are not well defined wet and dry seasons, the streams lack seasonal high and low water periods. Rather, a basal-flow occurs all year round coupled to ephemeral peak floodings following heavy rains. 
The samplings were performed during the basalflow conditions thus, avoiding peak floods.

The borders of these streams are not forested, but rather contain abundant riparian vegetation. In the lower stretches, the streams run through the Río-de-la-Plata coastal plain (Cavallotto 2002), a lowland area covered with wetlands and separated from the Río de la Plata by a small forested ridge. The largest streamsPescado, Buñirigo, and Rodriguez-traverse the ridge and remain in permanent contact with the Río de la Plata. The lower stretch of the Rodríguez was channelized to prevent floodings in the urban areas. The Juan Blanco and Zapata streams extend into the coastal wetland, and as such, do not remain in contact with the Río de la Plata; moreover, their water can spill over the ridge when heavy rains occur (Table I).

\section{Environmental variables}

Before each fish sampling, environmental parameters were measured in situ. Water temperature and dissolved oxygen concentration were measured with a YSI 51B oxymeter (YSI Incorporated, Yellow Springs, OH, USA), the $\mathrm{pH}$ with a Hanna checker (Hanna Instruments, Woonsocket, RI, USA), the conductivity with a Hanna HI 8733 conductivity meter, and the stream depth with a graduated rod. Water samples were taken for nutrient analysis and then immediately passed through Whatman GF/C filters having a 1.2- $\mu \mathrm{m}$ pore size (Whatman Incorporated, Clifton, NJ, USA) and transported to the laboratory on ice. The concentration of soluble reactive phosphorus (SRP), ammonium, and nitrate were measured following APHA (1998). The concentration of non-ionized ammonia was estimated from the ionizedammonia concentration, $\mathrm{pH}$, and temperature after Emerson et al. (1975).

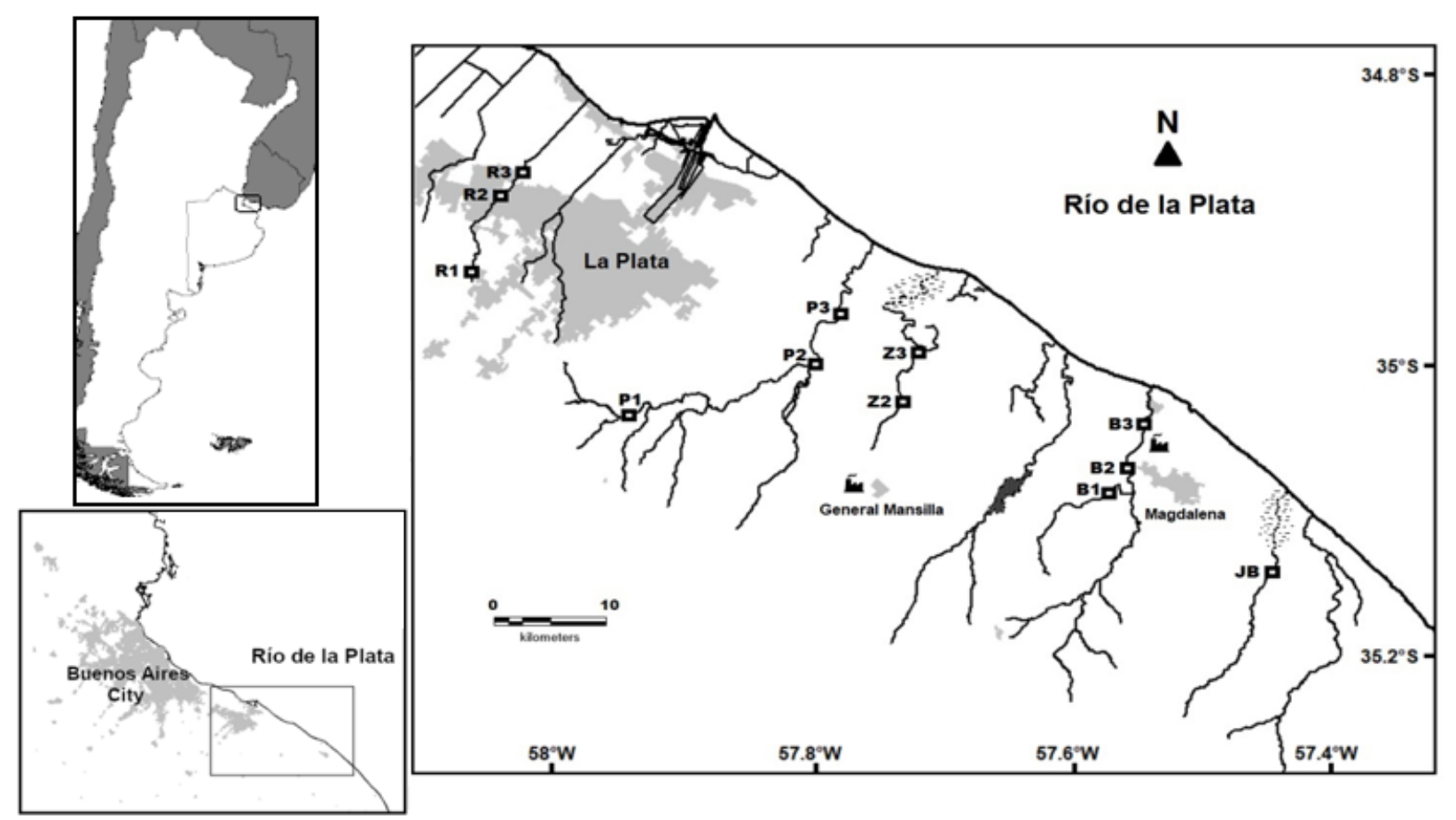

Figure 1. Study sites in pampean streams, Buenos Aires province, Argentina. R1-R3: Rodríguez, P1-P3: Pescado, Z2 and Z3: Zapata, B1-B3: Buñirigo, JB: Juan Blanco. 
Table I. Features of the study sites on pampean streams, Buenos Aires province, Argentina. Distance to the mouth $(\mathrm{km})$ measured in length of the downstream river course.

\begin{tabular}{|c|c|c|c|c|c|}
\hline Site & Code & $\begin{array}{c}\text { No of } \\
\text { samples }\end{array}$ & Main land use & Depth (cm) & $\begin{array}{c}\text { Distance to } \\
\text { the mouth } \\
\text { (km) }\end{array}$ \\
\hline Rodríguez upper stretch & R1 & 3 & intensive urban use & $24.7 \pm 0.6$ & 16.9 \\
\hline Rodriguez middle stretch & R2 & 2 & intensive urban use & $32.5 \pm 3.5$ & 9.8 \\
\hline Rodriguez lower stretch & R3 & 2 & intensive urban use & $51.5 \pm 4.9$ & 7.2 \\
\hline Pescado upper stretch & P1 & 5 & livestock & $84.2 \pm 33.7$ & 31 \\
\hline Pescado middle stretch & P2 & 4 & livestock & $65.8 \pm 16$ & 13.7 \\
\hline Pescado lower stretch & P3 & 4 & livestock & $95 \pm 8.2$ & 8.2 \\
\hline Zapata middle stretch & Z2 & 2 & livestock, dairy, low-impact & $58 \pm 4.2$ & 19 \\
\hline Zapata downstream stretch & Z3 & 3 & livestock & $75 \pm 5$ & 14 \\
\hline Buñirigo upstream stretch & B1 & 3 & livestock & $54.7 \pm 16.7$ & 12.9 \\
\hline Buñirigo middle stretch & B2 & 4 & livestock & $116 \pm 27.7$ & 7.6 \\
\hline Buñirigo downstream & B3 & 3 & livestock, food industry & $40.3 \pm 7.6$ & 4.5 \\
\hline Juan Blancotch & tannery & $104 \pm 34.4$ & 7.6 \\
\hline
\end{tabular}

\section{Fish sampling and data analysis}

The same fishing gear and sampling effort were used along all the surveys. Before each sampling, a section of the stream was completely closed off with a net $1 \mathrm{~m}$ high and with a 5-mm mesh. In each sampling, a seine net-of 15-m width, 1-m height, Icod end $1.5 \mathrm{~m}$, and mesh of 50-10 $\mathrm{mm}$-was dragged along a 50-m stretch towards the fixed net. The study sites were sampled until no major changes in species richness or abundance was registered, with two successive seine hauls being enough to assess the assemblage composition. Care during collection and handling of fish for this study complied with the Buenos Aires Province (Argentina) Wildlife and Fisheries Authority guidelines and policies (Law 11,477).

Easily identified species were determined and weighed in the field with an Ohaus 0.5-gprecision balance. All other specimens captured were initially preserved in $10 \%$, formaldehyde later replaced by $70 \%$ aqueous ethanol for routine laboratory determination. The fish were identified following Azpelicueta \& Braga (1991), Braga (1993), Braga (1994), Aquino (1997), Reis \& Pereira (2000), Casciotta et al. (2005), Miquelarena \& Menni (2004), and Almirón et al. (2015). Updates in the taxonomy were reviewed following Mirande \& Koerber (2015), Koerber et al. (2017), and Rosso et al. (2018). Voucher specimens were stored at the ichthyological collection of the Félix de Azara Natural History Foundation (CFA-IC), Buenos Aires, Argentina. Fish species typically recorded in pampean streams (Di Marzio et al. 2003, Remes Lenicov et al. 2005, Fernández et al. 2008, Colautti et al. 2009, Granitto et al. 2016) hereafter will be referred as "pampean" species, to differentiate them from the species most commonly reported in the Río de la Plata (Ringuelet et al. 1967, CARUCARP 2012, 2016), those being hereafter referred as "riverine" species. 


\section{Statistical analysis}

The biological data matrix was composed of relative abundance. The species whose total relative abundance was lower than $0.25 \%$ were eliminated from the analysis to reduce the influence of rare species. Thirty one species were eliminated for the multivariate analysis. The biological data matrix was then composed of the relative abundance of 24 species and 39 samples. A Detrended Correspondence Analysis (DCA) was performed. Since the length of the gradient for the first axis was 4.2 units of standard deviation, unimodal response models were used (Ter Braak \& Smilauer 1998, Leps \& Smilauer 2003). A Correspondence Analysis (CA) was performed to assess the distribution of the sampled sites in an exploratory fashion. Nutrient concentration, richness, the Shannon index (Magurran 1988), abundance, and biomass were compared by means of the Student $t$-test. Whenever data did not fit a normal distribution (i. e., abundance and biomass), the nonparametric equivalent ( $i$. e., the Mann-Whitney test) was performed. The level of significance used was $p<0.05$.

In order to evaluate if differences existed in the number of riverine species between stream reaches, a nonparametric one-way analysis of variance (i. e., Kruskal-Wallis) and a pairwise multiple comparisons were performed.

Relationships between the environmental variables and the composition of the fish assemblages were studied with a partial Canonical Correspondence Analysis (CCA). Because environmental variables had different units of measurement, the data were normalized. The environmental matrix consisted of 5 variables $\left(\mathrm{O}_{2}\right.$,

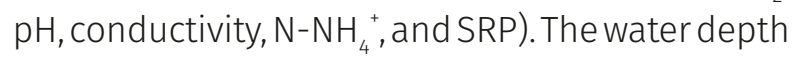
and temperature were treated as covariables. The inflation factor (Ter Braak \& Smilauer 1998) was used in order to assess multicollinearity among the selected environmental variables; with values higher than 20 indicating collinearity.

\section{RESULTS}

The Correspondence Analysis pointed to the existence of two patterns defined by the relation to the Río de la Plata in the first and land use in the second axis (Fig. 2). The sites close to and in permanent contact with the Río de la Plata-i. e., P3 and B3- were surrounded by livestock fields.

The sites were therefore sorted into two groups: the reaches surrounded by urban land use on the Rodriguez Stream (R1-R3), along with the Zapata Stream, bordered by a small rural urbanization and a dairy in the basin (Z2 \& Z3), were grouped together, and will hereafter be termed the more impacted (MI); whereas the rest of the sites, located on streams surrounded by pasturing livestock (P1-P3, B1-B3, and JB), constituted the second group, which will hereafter be called the less impacted (LI).

The water conductivity did not evidence significant differences between the MI and the LI groups (Table II). The dissolved oxygen concentration was generally high at most sites although sites in the MI group occasionally registered low concentrations: 0.3 and $0.5 \mathrm{mg} / \mathrm{l}$ at $\mathrm{R} 1$ and $\mathrm{Z3}$, respectively.

Soluble reactive phosphorus, nitrate, and ammonium concentrations were significantly higher in the $\mathrm{MI}$ than in the LI group (MannWhitney test; $p<0.05$; Fig. 3 ). The maximum concentrations were recorded at $5 \mathrm{mg} / \mathrm{l}$ of SRP and $15 \mathrm{mg} / \mathrm{l}$ of $\mathrm{N}-\mathrm{NH}_{4}^{+1}$ at site R1. The non-ionized ammonia concentrations calculated were high, attaining maxima of 0.8 and $0.9 \mathrm{mg} / \mathrm{l}$ on two occasions at Site Z2.

A total of 18,061 fish were collected, corresponding to 55 species belonging to 22 families and nine orders (Table SI - Supplementary Material). The order Characiformes was characterized by the largest species richness at 28 (50.9\%), followed by the Siluriformes, at 16 (29.1\%); the Cichliformes at 3 
(5.4\%); the Cyprinodontiformes and Perciformes at 2 (3.6\%); and the Clupeiformes, Cypriniformes, Atheriniformes, and Synbranchiformes with a single species each. The Characidae family contained the largest number of species (18). In terms of abundance, a similar pattern was observed. The Characiformes and Siluriformes were widely dominant, accounting for 54.2 and $39.9 \%$ of the total catch, respectively.

The species richness, the diversity (t-test), abundance and the biomass (Mann-Whitney test) were significantly higher in the $\mathrm{LI}$ than in the $\mathrm{MI}$ group (Fig. 4). The fish assemblage in the urban Rodriguez Stream contained only 7 species. Of the total catch, $95 \%$ was represented by only two species: Cnesterodon decemmaculatus (90\%) and Corydoras paleatus (4.8\%).

The number of riverine species in the Pescado and Buñirigo stream, in permanent contact with the Río de la Plata, was significantly higher in the downstream than in the upstream reaches (Kruskal-Wallis test, Dunn's method for multiple comparison).

The CCA analysis indicated that the relationship between sites and species with environmental variables was significant, the significance of the first and all the canonical axes being $p=0.002$. The percent variance contributed by the covariables (depth and temperature) was comparatively modest (5.3\%). The maximum value of the inflation factor of environmental variables was 3.2, indicating the absence of multicollinearity among the set of selected variables.

The first and second axes of the CCA accounted for $76.6 \%$ of the relationship between species and the environmental variables. The conductivity (0.83), dissolved oxygen (0.31), and $\mathrm{pH}$ (0.21) were positively correlated with the first axis, while the SRP $(-0.43)$ and ammonium $(-0.26)$ were negatively correlated. The SRP and ammonium were the environmental variables that

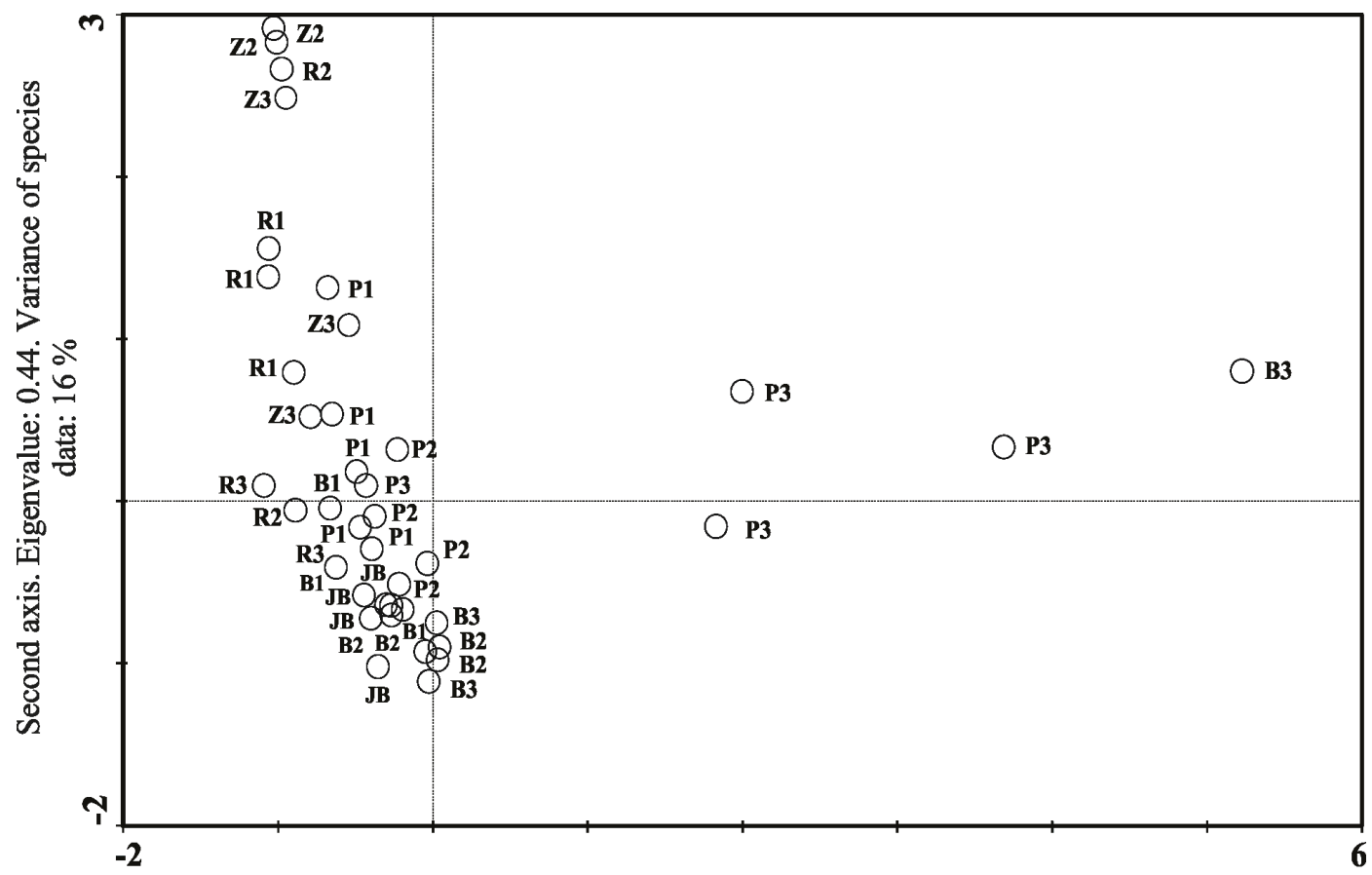

First axis. Eigenvalue: 0.62 . Variance of species data: $22.4 \%$

Figure 2. Correspondence analysis. Scatter plot of samples sites in pampean streams, Buenos Aires province, Argentina. R1-R3: Rodríguez, P1-P3: Pescado, Z2 and Z3: Zapata, B1-B3: Buñirigo, JB: Juan Blanco. 


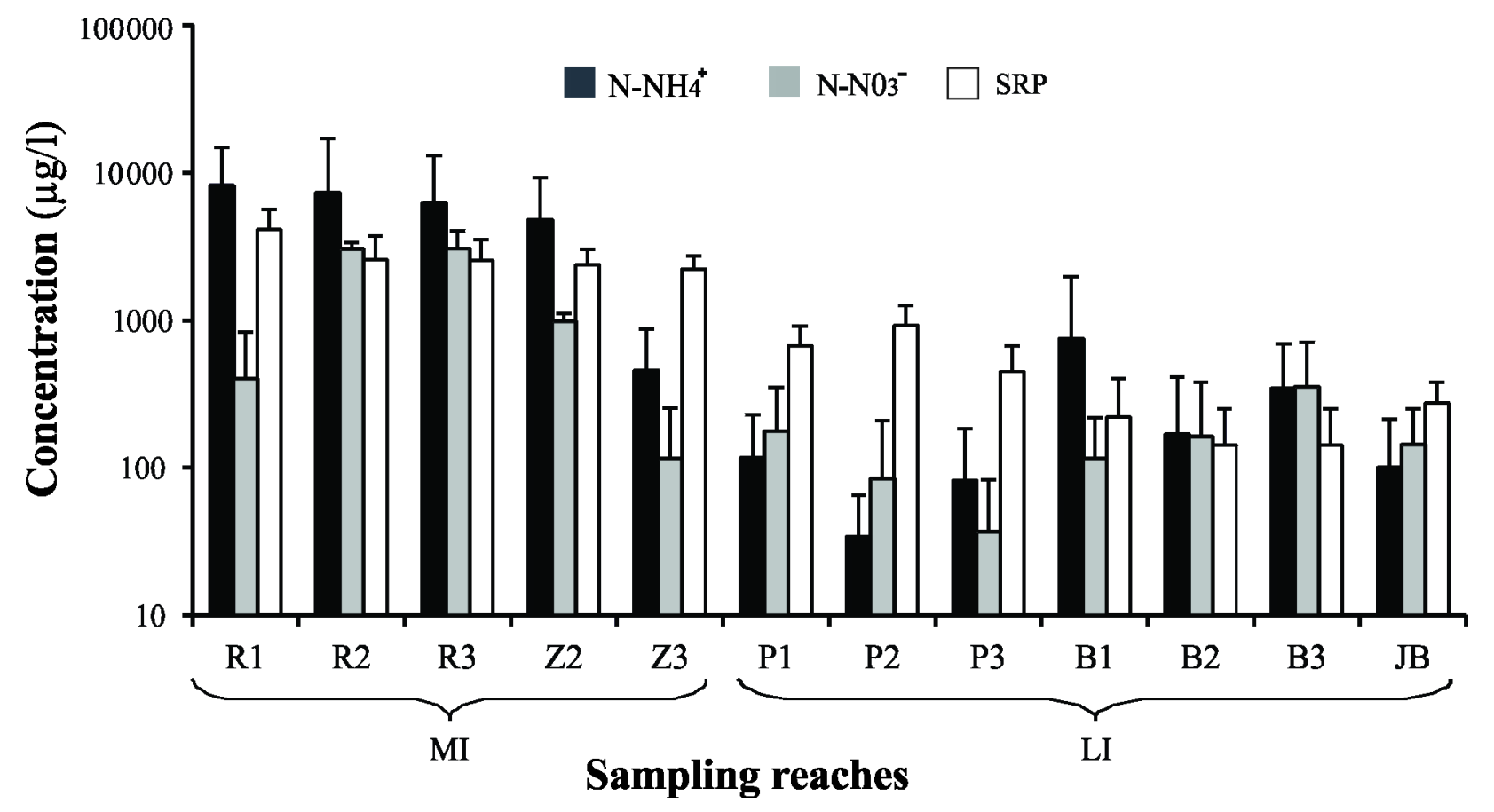

Figure 3. Mean concentration of nutrients in pampean streams sampled, Buenos Aires province, Argentina. Ml: more impacted group; Ll: less impacted group.
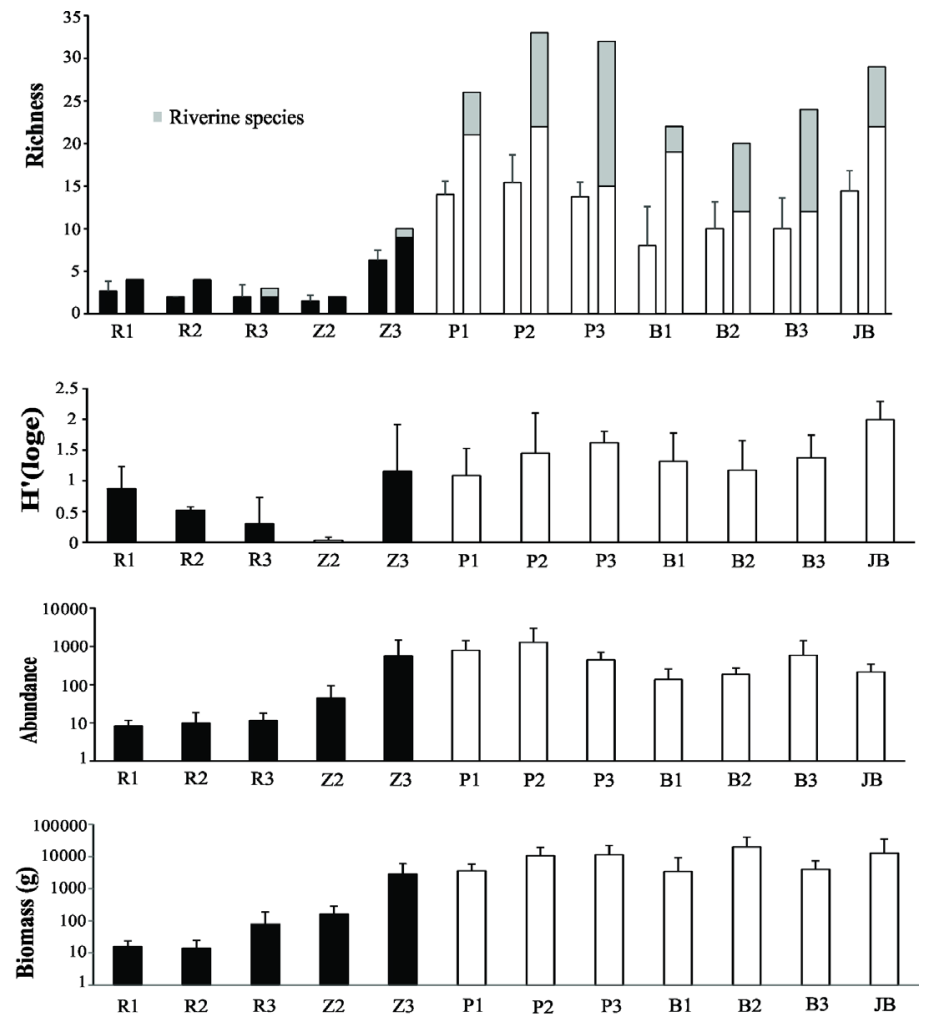

Sampling reaches

Figure 4. Mean species richness (first bar), total richness (second bar), Shannon diversity ( $\left.H^{\prime}\right)$, abundance and biomass, in all stream reaches of pampean streams, Buenos Aires province, Argentina. Black bars: MI reaches; white bars: $\mathrm{LI}$ reaches. 


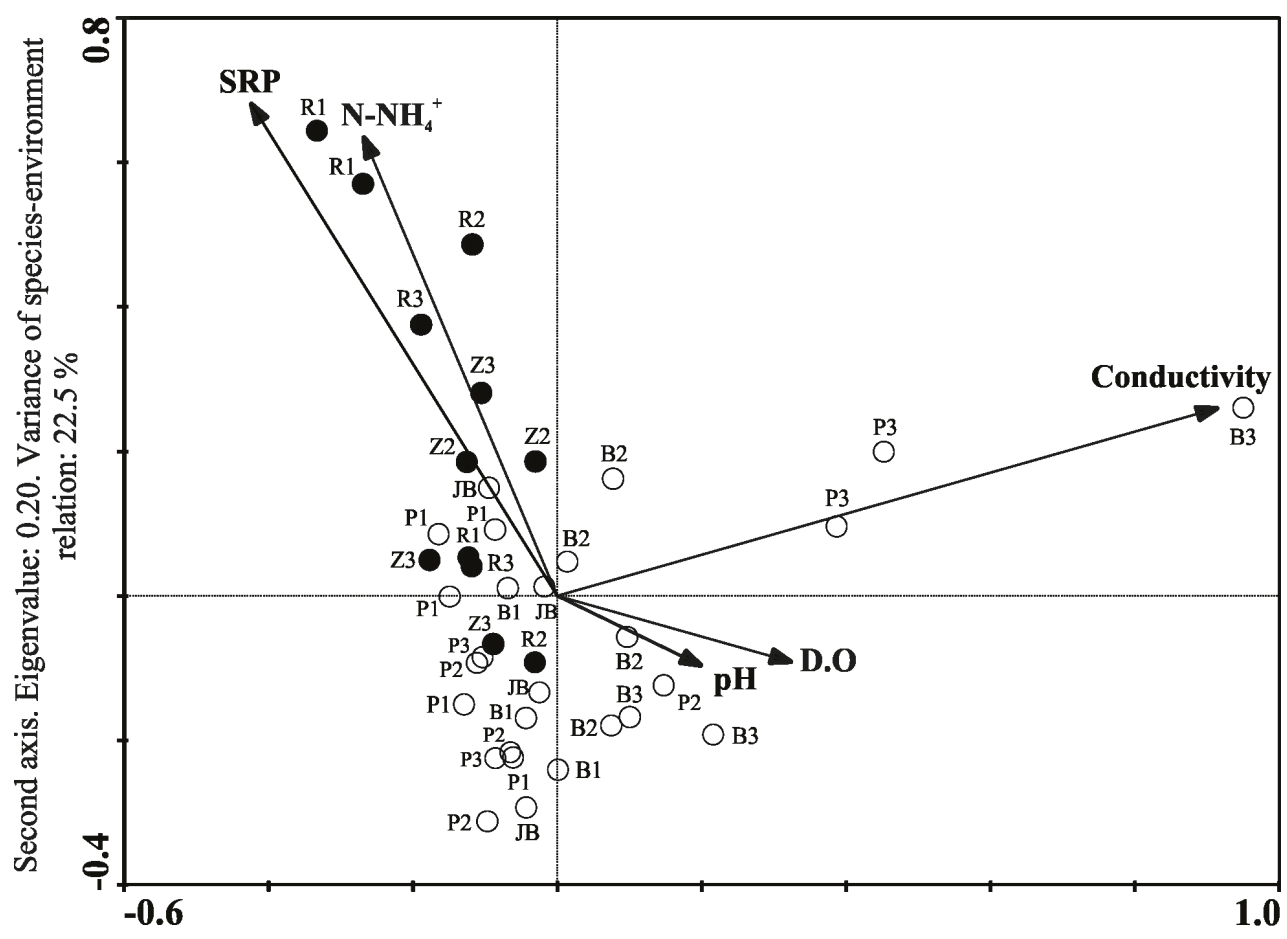

Figure 5. Canonical Correspondence Analysis. Biplot of stream reaches and the environmental variables measured in pampean streams, Buenos Aires province, Argentina. The LI stretches are represented by white dots and the MI stretches by black dots. The arrows point to the environmental variables.

First axis. Eigenvalue: 0.48 . Variance of species-environment relation: $54.1 \%$

exhibited the highest positive correlation with the second axis (0.61 and 0.54 respectively), followed by the conductivity (0.20). In the CCA biplot of the environmental variables in the stream reaches, the sites related to the highest values on the first axis were the lower reaches of the streams draining livestock basins and in permanent connection with the Río de la Plata (Fig. 5).

The fish assemblage was characterized by a dominance of juvenile stages of the riverine species such as Parapimelodus valenciennis, Iheringichthys labrosus, Pachyurus bonariensis, and Plagioscion ternetzi (Fig. 6). The sites related to the higher values of the second axis belong the $\mathrm{MI}$ group and were associated with the worse environmental conditions characterized by high concentrations of ammonium, SRP and low dissolved oxygen (Fig. 5). The dominant species in these reaches were Corydoras paleatus, Rhamdia quelen, and Cnesterodon decemmaculatus.
Nevertheless, the LI sites were associated with lower nutrient and higher dissolved oxygen concentrations. With the exception of Pimelodus maculatus and Prochilodus lineatus, the assemblage was characterized by species typically recorded in pampean streams representing good environmental conditions (Fig. 6). Most of the assemblages were represented by species of the family Characidae: Charax stenoperus, Bryconamericus iheringii, Astyanx rutilus, A. eigenmanniorum, Oligosarcus oligolepis, O. jenynsii, and Pseudocorynopoma doriae. Other species associated with the LI sites belonged to other families, such as Cyphocharax voga, Hoplias argentinensis, Pimelodella laticeps, Otocinclus arnoldi, Loricariichthys anus, Hypostomus commersoni, Jenynsia lineata, and Australoheros facetus. 


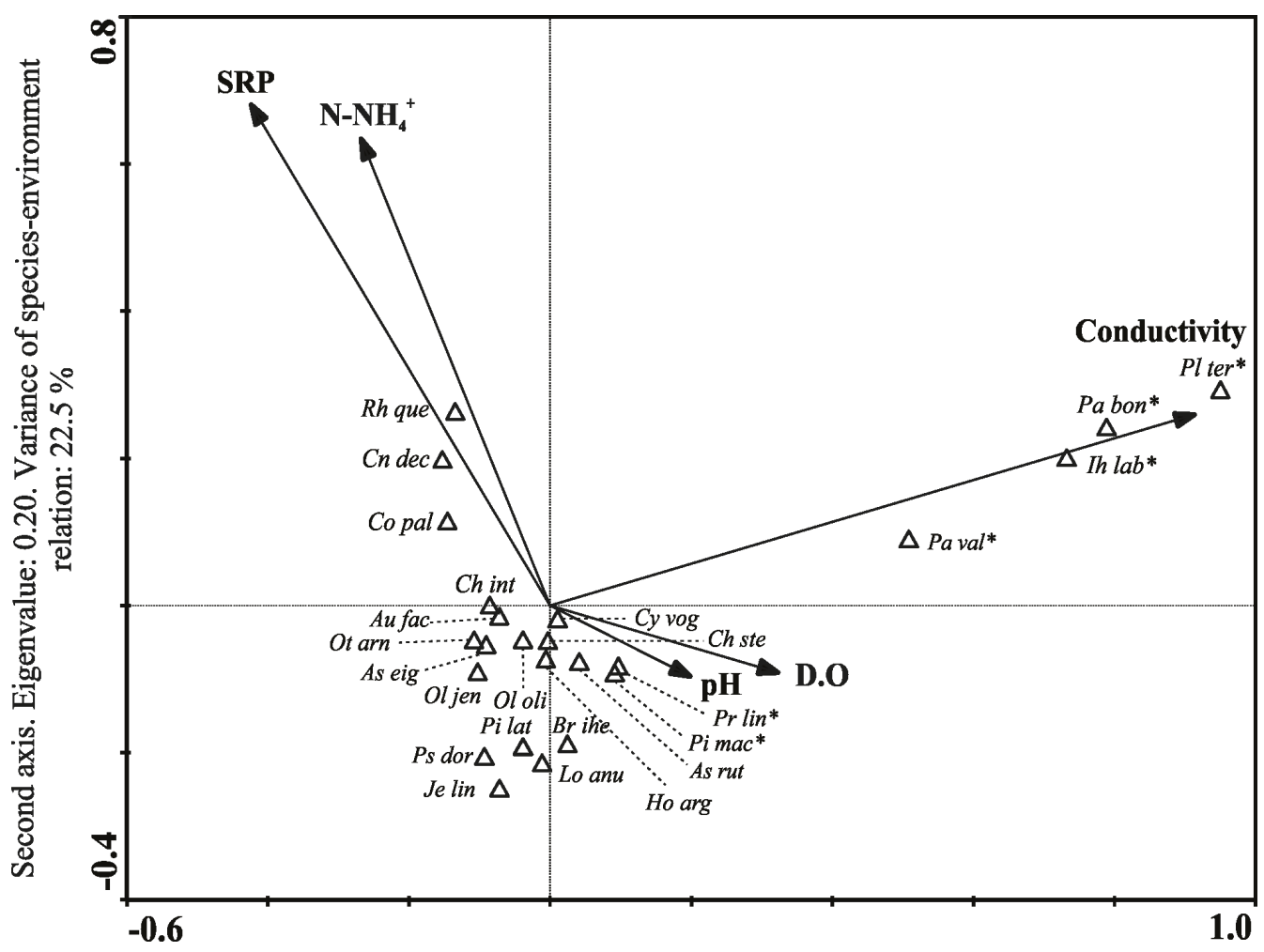

First axis. Eigenvalue: 0.48. Variance of species-environment relation: $54.1 \%$

Figure 6. Canonical correspondence analysis. Biplot of species and environmental variables in measured in pampean streams, Buenos Aires province, Argentina. Species with an asterisk are riverine. Cn dec, Cnesterodon decemmaculatus; Rh que, Rhamdia quelen; Co pal, Corydoras paleatus; Ch int, Cheirodon interruptus; Ot arn, Otocinclus arnoldi; As eig, Astyanax eigenmanniorum; Ch ste, Charax stenopterus; As rut, Astyanax rutilus; Cy vog, Cyphocharax voga; Pr lin, Prochilodus lineatus; Pi mac, Pimelodus maculatus; Ol oli, Oligosarcus oligolepis; Ol jen, Oligosarcus jenynsii; Au fac, Australoheros facetus; Ho arg, Hoplias argentinenensis, Ps dor, Pseudocorynopoma doriae; Pi lat, Pimelodella laticeps; Je lin, Jenynsia lineata; Lo anu, Loricariichthys anus; Br ihe, Bryconamericus iheringii; Pa val, Parapimelodus valenciennis; Ih lab, Iheringichthys labrosus; Pa bon, Pachyurus bonariensis; Pl ter, Plagioscion ternetzi

\section{DISCUSSION}

Nutrient concentrations were an order of magnitude higher in the reaches associated with the MI group than those of the LI group, thus, pointing to the effect on adjacent streams of contaminant loads from urban and land used by industry. Soluble reactive phosphorus concentrations reported in the MI group were also an order of magnitude higher than previously reported for other pampean streams. Feijoo \& Lombardo (2007) studied 41 rural streams in the Buenos Aires province, and reported SRP values in the range of 52-433 $\mu \mathrm{g} / \mathrm{l}$, which values overlap the concentrations measured in the present LI group. Likewise, Mugni et al. (2013) recorded SRP concentrations in the range of $144-456 \mu \mathrm{g} / \mathrm{l}$ in a pampean stream surrounded by land use involving livestock and agriculture. High nutrient concentrations have been repeatedly reported in urban streams. Loiselle et al. (2016) studied nutrient concentrations in 150 streams in South, Central, and North America and reported that the concentration of SRP correlated with urban land coverage and population density. In Midwestern agricultural basins, USA, urban areas 


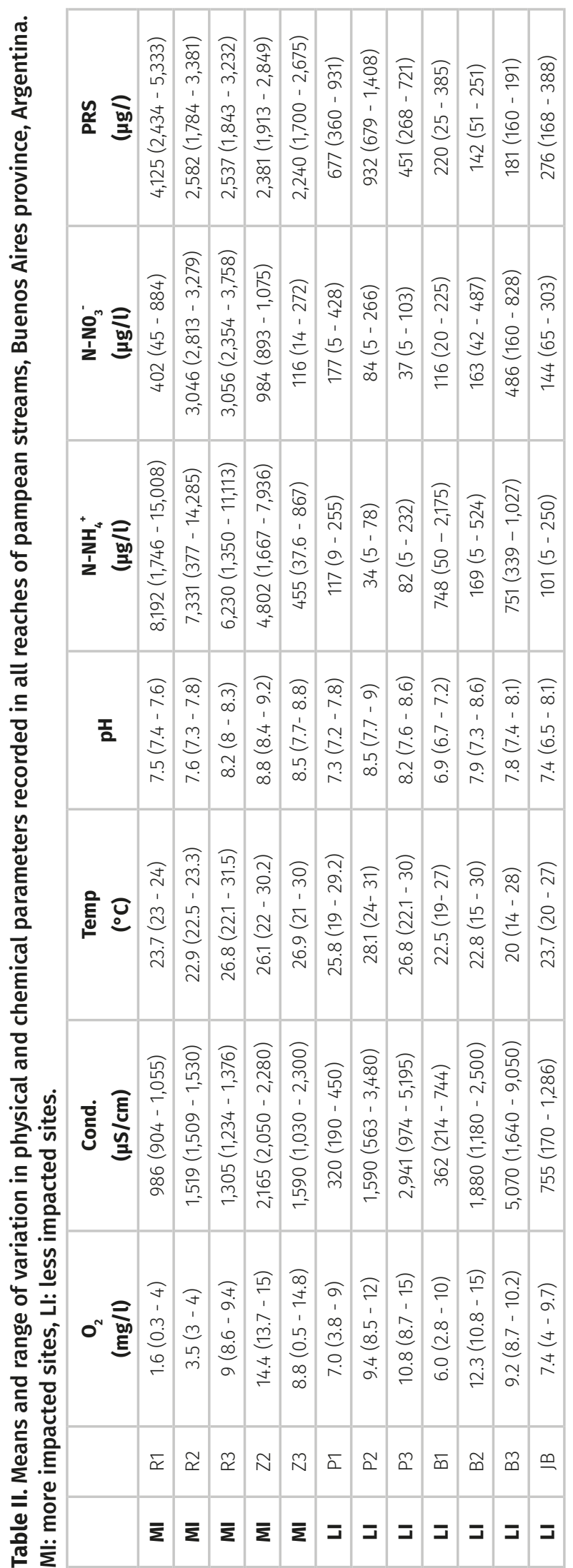

were found to strongly influence the dissolved-P concentrations in streams despite representing only $5 \%$ of the area of the basin (Osborne \& Wiley 1988). In Great Britain, even sparsely populated rural settlements have been reported to cause significant nutrient enrichment in lowland streams (Jarvie et al. 2010).

In the present study, occasional peaks of non-ionized ammonia in the Zapata Stream of the MI Group (0.8 and $0.9 \mathrm{mg} / \mathrm{l}$ ) were higher than the lethal concentrations reported in the literature, with fish mortality starting at roughly $0.6 \mathrm{mg} / \mathrm{l}$ (Durborow et al. 1997). The reported 96h-LC50 of non-ionized ammonia for freshwater fish species ranges between 0.068 and $2 \mathrm{mg} / \mathrm{l}$ (Eddy 2005).

Dissolved oxygen concentrations occasionally dropped to quite low values in the Rodríguez and Zapata streams of the MI Group ( 0.3 and $0.5 \mathrm{mg} / \mathrm{l}$, respectively). Rimoldi et al. (2018), in a study of the urban El Gato Stream located close $(3.5 \mathrm{~km})$ to the Rodríguez Stream, likewise had recorded similarly low dissolved oxygen concentrations (0.5-1.3 mg/l). Minimum oxygen concentrations fell below the LC50 of the common pampean stream species Pimelodella laticeps and Corydoras paleatus reported by Gómez 1993 (0.88 and 0.72 mg/l, respectively). In the same study, the author also reported sublethal effects such as equilibrium loss in the $0.26-1.53 \mathrm{mg} / \mathrm{l}$ range for several Neotropicalfish species. Smale \& Rabeni (1995) in Missouri, USA demonstrated that the ventilation and opercular movement in 35 stream species of fish ceased when the dissolved oxygen concentration decreased below 0.49-1.6 mg/l. Corydoras paleatus and C. decemmaculatus, the dominant species at the most impacted sites in the present study are comparatively tolerant to hypoxia. Corydoras paleatus makes use of the caudal portion of the intestine as an accessory air-breathing organ (Plaul et al. 2016), 
while $\mathrm{C}$. decemmaculatus takes advantage of the higher dissolved oxygen concentration in the uppermost layer of the water without needing to alter its swimming posture as a result of an upward orientation of its mouth and a flattening of its head (Lewis 1970, Kramer \& Mehegan 1981). Rimoldi et al. (2018) reported mortalities of up to $60 \%$ for C. decemmaculatus in laboratory exposures to the urban El Gato Stream water. Furthermore, several other contaminants have been determined in the El Gato Stream, such as metals. The present evidence suggests that the overall effect of the combined contaminant loads results in low species richness, as determined in the Rodriguez and Zapata streams. In the present study, the downstream R3 site evidenced low richness at only 3 species, of which one was riverine. In 1999, 19 species had been registered throughout the Rodriguez stream (Remes Lenicov et al. 2005). Those authors had observed an increase in richness downstream, with 16 species had recorded at the downstream site, nine of which were pampean and seven riverine. The present evidence suggests that increased water quality deterioration caused the disappearance of sensitive species and affected the entrance of riverine species from the Río de la Plata into that lower stretch of the Rodriguez Stream. Fish assemblages in the Cahaba River, Alabama, USA, evidenced changes in the relative abundance, the disappearance of two species was registered between 1984 and 1995-1997, in accordance with increased urbanization and water quality deterioration (Onorato et al. 2000). Wang et al. (2000) studied 47 streams in southeastern Wisconsin, recorded decreases in the number of species, the density, and the biotic integrity at sites where urbanization had increased by only 10\% between 1970 and 1990. Weaver \& Garman (1994), at the Tuckahoe Creek watershed, Virginia, USA, reported a lower abundance and diversity and 6 fewer species in 1990, compared with the fish composition reported in 1958 as a result of increased urbanization. The authors concluded that urban land use was related to the increase in toxic and nutrient loads, removal of the riparian areas, and increased sedimentation. Changes in the fish assemblages were related to the decrease in the species sensitive to contamination along with dominance of trophic generalists.

The three dominant species at the MI sites in the present study (C. decemaculatus, $C$. paleatus and $R$. quelen) have been reported previously as dominant in contaminated environments. Corydoras paleatus and C. decemmaculatus were abundant downstream in the Suquia River of Córdoba city, Argentina, where high nutrients and low dissolved oxygen concentrations were recorded (Hued \& Bistoni 2005). Similarly, both species were also abundant in accordance with high nutrients and low dissolved oxygen concentrations at contaminated streams adjacent to cultivated plots and dairies in the basin of the Santa Lucía River, Uruguay (Chalar et al. 2013). Rhamdia quelen attained the highest biomass in urban streams in Maringá city, Brazil (Cunico et al. 2006) and was the most abundant species in the most urbanized areas around Toledo city, Paraná, Brazil (Daga et al. 2012). All three dominant species at the $\mathrm{MI}$ sites are omnivores, likely profiting from the increased loads of allochthonous organic matter. Cunico et al. (2011) reported that benthic omnivores predominated in fish assemblages in urban streams in the USA and Brazil.

On the other hand, in the present study, the fish assemblages at the LI sites surrounded by pastures devoted to livestock raising, evidenced a greater number of species belonging to several taxonomic and ecological groups. Species of the orders Characiformes and Siluriformes were predominant in the assemblage. Although omnivorous species were also present, different 
trophic groups were well represented, i. e., the piscivorous by Oligosarcus jenynsii, O. oligolepis, and Hoplias argentinensis (Barla et al. 2003); the invertivorous by Pseudocorynopoma doriae (Ferriz et al. 2012, Brancolini et al. 2015); and the detritivorous by Cyphocharax voga (González Sagrario \& Ferrero 2013). Loricariichthys anus and Hypostomus commersoni were also common in the LI streams. This pattern of Characiformes and Siluriformes dominance is consistent with the expected composition in the Neotropical region (Lévêque et al. 2008, Reis 2016). Several authors reported that the dominance of those two orders with a broad trophic spectrum are accordingly indicators of balanced assemblages associated with good environmental conditions (Araujo et al. 2003, Ferreira \& Casatti 2006, Pinto et al. 2006, Bastos dos Santos \& Esteves 2015).

The number of riverine species in the $\mathrm{LI}$ streams in permanent contact to the Río de la Plata was significantly higher in the downstream than in the upstream reaches. The most abundant fish at these sites were the juveniles of species from the Río de la Plata, such as Parapimelodus valenciennis, Iheringichthys labrosus, Pachyurus bonariensis, and Plagioscion ternetzi.

The increased conductivity recorded at the downstream sites of the Buñirigo and Pescado streams (Figs. 5 and 6) was produced by the higher groundwater contribution during dry periods (Mugni 2009, Bazán et al. 2011). Close to the mouth of the Río de la Plata, the Buñirigo Stream of the $\mathrm{LI}$ group receives loads from two industries. The different composition of the benthic-invertebrate assemblages at this site have been interpreted as the result of deterioration in the sediment quality (Ocón \& Rodrigues Capítulo 2012). Nevertheless, in the present study, no effect was observed on the fish assemblages presumably because of the attenuating effect of the Río de la Plata. A high proportion of riverine juveniles were recorded in the lower stretches of the Buñirigo and Pescado streams (Fig. 5), pointing to the influence of the Río de la Plata close to the mouths of those streams. Hitt \& Angermeier (2008) studied 308 wadeable streams in the Mid-Atlantic Highland region, USA and observed that sites near the confluences of mainstream rivers supported a greaterspecies richness along with an abundance of riverine species of the catostomid, cyprinid, and ictalurid families than did sites farther upstream from those confluences. The authors emphasized the significant role of stream-river connectivity in structuring the richness and abundance of those families owing to their movement from the rivers to the streams during seasonal spawning migrations. Juveniles of the riverine Micropogonias furnieri were by far the most abundant species in the lower stretches of the Pando (Acuña-Plavan et al. 2010, Gurdek \& Acuña-Plavan 2016) and Solís Chico (AcuñaPlavan et al. 2017) streams and the Ajo River (Solari et al. 2015) close to the mouths of those rivers on the Río de la Plata. The high abundance of juvenile riverine species underscores the essential function of the tributaries as nurseries of riverine assemblages. Therefore, those sites play a major role in the population dynamics of several species that inhabit the Río de la Plata and as such represent priority areas for protection and conservation.

\section{CONCLUSIONS}

This study demonstrated that streams running through land used by industry and urbanized land were characterized by higher nutrient and low oxygen concentration and a significantly lower species richness and abundance of fish because of the disappearance of the most sensitive species. By contrast, streams surrounded by land devoted to livestock 
breeding evidenced good water quality and fish assemblages that were characterized by a higher species richness and abundance. The evidence garnered in our study suggests that a deterioration in water quality is the cause of the observed impoverishment of fish assemblages in the urban pampean streams.

The downstream sites in the less impacted streams contained fish assemblages in which the juvenile stages of riverine species were dominant, pointing to the significance of the preservation of those habitats in the maintenance of the fish fauna in the Rio de la Plata.

\section{Acknowledgments}

The authors thank the Argentine National Scientific and Technical Research Council (CONICET) and the financial support of the Argentine National Agency for the Promotion of Science and Technology (ANPCYT; PICT 2016- 0902). The authors likewise thank Lucila Protogino for support in the specific identification of some specimens. We are grateful to the Maritime and River Development Office, Ministry of Agro-Industry, Buenos Aires province, for scientific collection permission. Dr. Donald F. Haggerty, a retired academic career investigator and native English speaker, edited the final version of the manuscript.

\section{REFERENCES}

ACUÑA-PLAVAN A, GURDEK R, MUÑOZ N, GUTIERREZ JM, SPÓSITO M, CORREA P \& CARIDE A. 2017. Seasonal composition, abundance and biomass of the subestuarine fish assemblage in Solís Chico (Río de la Plata estuary, Uruguay). Braz J Biol 77(3): 622-631.

ACUÑA-PLAVAN A, PASSADORE C \& GIMENEZ L. 2010. Fish assemblage in a temperate estuary on the uruguayan coast: seasonal variation and environmental influence. Braz J Oceanogr 58(4): 299-314.

ALLAN JD. 2004. Landscapes \& Riverscapes: The Influence of Land Use on Stream Ecosystems. Annu Rev Ecol Evol Syst 35: 257-284.

ALMIRÓN A, CASCIOTTA JR, CIOTEK L \& GIORGIS P. 2015. Guía de los peces del Parque Nacional Pre-Delta. Buenos Aires: Administración de Parques acionales, $1^{\text {st }}$ ed., 218 p.
APHA - AMERICAN PUBLIC HEALTH ASSOCIATION. 1998. Standard methods for the examination of water and wastewater, $20^{\text {th }}$ ed., $1220 \mathrm{p}$.

AQUINO AE. 1997. Las especies de Hypoptomatinae (Pisces, Siluriformes, Loricariidae) en la Argentina. Rev Ict 5: 5-21.

ARAUJO FG, FICHBERG I, PINTO BCT \& PEIXOTO GM. 2003. A Preliminary Index of Biotic Integrity for Monitoring the Condition of the Rio Paraiba do Sul, Southeast Brazil. Environ Manag 32(4): 516-526.

AZPELICUETA MM \& BRAGA L. 1991. Los Curimátidos en Argentina. In: Castellanos ZA (Ed), Fauna de agua dulce de la República Argentina 40(1): 1-55.

BARLA MJ, VERA MS \& O'BRIEN ED. 2003. Peces piscivoros en lagunas de la cuenca superior del río Salado (Buenos Aires, Argentina): abundancia relativa y autoecología. Ecología Austral 13(2): 205-214.

BAZÁN JM, ALBERINO JC VARRIANO N, CARIELLO J, KRUSE E, ROJO A, DELUCHI M \& LAURENCENA P. 2011. Estudio hidrológico y calidad de agua de las cuencas del arroyo el Pescado y del Gato en los partidos de La Plata, Berisso y Ensenada. In: Contaminación Atmosférica e Hídrica en Argentina Integrador para la Mitigación de la Contaminación Atmosférica. Tercera Reunión Anual PROIMCA Primera Reunión Anual PRODECA, p. 435-445. Available at: http://sicyt.scyt.rec.utn.edu.ar/scyt/proimca/LIBRO_ PROIMCA_2011.pdf. Accessed on January 2020.

BOET P, BELLIARD J, BERREDI-DIT-THOMAS R \& TALES E. 1999. Multiple human impacts by the City of Paris on fish communities in the Seine River basin, France. Hydrobiologia 410: 59-68.

BRAGA L. 1993. Los Anostomidae (Pisces, Characiformes) de Argentina. In: Castellanos ZA (Ed), Fauna de agua dulce de la República Argentina, La Plata 40(3): 1-61.

BRAGA L. 1994. Los Characidae de Argentina de las subfamilias Cynopotaminae y Ancestrorhynchinae. In: Castellanos ZA (Ed), Fauna de agua dulce de la República Argentina, La Plata 40(6): 1-45.

BRANCOLINI F, MAROÑAS ME \& SENDRA ED. 2015. Dieta de Pseudocorynopoma doriae (Characiformes: Characidae) en el arroyo de La Choza, Buenos Aires, Argentina. Bio Acuát 30: 259-265.

CARU-CARP. 2012. Proyecto de evaluación de los recursos ícticos del bajo río Uruguay y el Río de la Plata interior. Informe de Campañas de invierno 2011 y verano 2012, 117 p. Available at: https://www.agroindustria.gob.ar/sitio/ areas/pesca_continental/informes/baja/index.php. Accessed on January 2020. 
CARU-CARP. 2016. Proyecto de evaluación de los recursos ícticos del bajo río Uruguay y el Río de la Plata interior. Informe de la Campana de Invierno 2016, 151 p. Available at: https://www.agroindustria.gob.ar/sitio/areas/pesca_ continental/informes/baja/index.php. Accessed on January 2020.

CASCIOTTA JR, ALMIRÓN A \& BECHARA J. 2005. Peces del Ibera: Hábitat y Diversidad. Buenos Aires: Grafikar, $1^{\text {st }}$ ed., 244 p.

CAVALLOtTO JL. 2002. Evolución holocena de la llanura costera del margen sur del Río de la Plata. Rev Asoc Geol Argent 57(4): 376-388.

CHALAR G, DELBENE L, GONZÁLEZ-BERGONZONI I \& AROCENA R. 2013. Fish assemblage changes along a trophic gradient induced by agricultural activities (Santa Lucía, Uruguay). Ecol Indic 24: 582-588.

COLAUTTI DC, MAROÑAS ME, SENDRA ED, PROTOGINO L, BRANCOLINI F \& CAMPANELLA D. 2009. Ictiofauna del Arroyo La Choza, cuenca del Río de la Reconquista (Buenos Aires, Argentina). Biol Acuá 26: 55-62.

CUNICO AM, AGOSTINHO AA \& LATINI JD. 2006. Influência da urbanização sobre as assembléias de peixes em três córregos de Maringá, Paraná. Rev Bras Zool 23(4): $1101-1110$.

CUNICO AM, ALLAN DJ \& AGOSTINHO AA. 2011. Functional convergence of fish assemblages in urban streams of Brazil and the United States. Ecol Indic 11(5): 1354-1359.

DAGA VS, GUBIANI EA, CUNICO AM \& BAUMGARTNER G. 2012. Effects of abiotic variables on the distribution of fish assemblages in streams with different anthropogenic activities in southern Brazil. Neotrop Ichthyol 10(3): 643-652.

DI MARZIO WD, TORTORELLI MC \& FREYRE LR. 2003. Diversidad de peces en un arroyo de llanura. Limnetica 22(3-4): 71-76.

DOS SANTOS FB \& ESTEVES EK. 2015. A Fish-Based Index of Biotic Integrity for the Assessment of Streams Located in a Sugarcane-Dominated Landscape in Southeastern Brazil. Environ Manage 56(2): 532-548.

DURBOROW RM, CROSBY DM \& BRUNSON MW. 1997. Ammonia in fish ponds. J Fish Res Board Can 32: 2379-2383.

EDDY FB. 2005. Ammonia in estuaries and effects on fish. J Fish Biol 67(6): 1495-1513.

EMERSON K, RUSSO RC, LUND RE \& THURSTON RV. 1975. Aqueous ammonia equilibrium calculations: effects of $\mathrm{pH}$ and temperature. J Fish Res Board Can 32(12): 2379-2383.
FEIJOO CS \& LOMBARDO RJ. 2007. Baseline water quality and macrophyte assemblages in Pampean streams: A regional approach. Water Res 41(7): 1399-1410.

FERNANDEZ EM, FERRIZ RA, BENTOS CA \& LOPEZ GR. 2008. Ichthyofauna of two streams in the high basin of the Samborombón River, Buenos Aires province, Argentina. Rev Mus Argent Cienc Nat 10(1): 147-154.

FERREIRA CP \& CASATTI L. 2006. Integridade biótica de um córrego na bacia do Alto Rio Paraná avaliada por meio da comunidade de peixes. Biota Neotrop 6(3): 1-25.

FERRIZ RA, FERNANDEZ EM, LÓPEZ GR \& BENTOS CA. 2012. Alimentación de Pseudocorynopoma doriai (Pisces: Characidae) en el arroyo El Portugués, provincia de Buenos Aires, Argentina. Revi Mus Argent Cienc Nat 14(2): 243-251.

GOMEZ SE. 1993. Concentración letal de oxígeno disuelto para Corydoras paleatus y Pimlodella laticeps (Pisces, Siluriformes). Rev Mus Arg Cien Nat 7(2): 31-45.

GONZÁLEZ SAGRARIO MDLA \& FERRERO L. 2013. The trophic role of Cyphocharax voga (Hensel 1869) according to foraging area and diet analysis in turbid shallow lakes. Fund Appl Limnol 183(1): 77-85.

GRANITTO M, ROSSO JJ, BOVERI MB \& RENNELLA AM. 2016. Impacto del uso del suelo sobre la condición de ribera en arroyos pampeanos y su relación con la estructura de la comunidad de peces. Biol Acuát 31: 19-27.

GURDEK R \& ACUÑA-PLAVAN A. 2016. Intra-annual lengthweight relationships for juveniles of Micropogonias furnieri (Desmarest, 1823) in a sub-estuarine system from Uruguay. Panam J Aquat Sci 11(2): 165-169.

HELMS BS, SCHOONOVER JE \& FEMINELLA JW. 2009. Assessing influences of hydrology, physicochemistry, and habitat on stream fish assemblages across changing Landscape. J Am Water Resour Ass 45(1): 157-169.

HERRERO A, MARTín I \& FERNÁNDEZ L. 2009. Alteración de servicios ecológicos del urbanismo privado en la región metropolitana de Buenos Aires. XI Jornadas de Investigación del Centro de Investigaciones Geográficas y del Departamento de Geografía, 12 y 13 de noviembre de 2009, La Plata, Argentina. EN: Actas. La Plata: UNLPFAHCE. Departamento de Geografía, 14 p. Available at: http://www.memoria.fahce.unlp.edu.ar/trab_eventos/ ev.818/ev.818.pdf. Accessed on January 2020.

HITT NP \& ANGERMEIER PL. 2008. River-stream connectivity affects fish bioassessment performance. Environ Manage 42(1): 132-150.

HUED AC \& BISTONI MA. 2005. Development and validation of a Biotic Index for evaluation of environmental quality 
in the central region of Argentina. Hydrobiologia 543: 279-298.

HURTADO MA, GIMENEZ JE \& CABRAL MG. 2006. Análisis ambiental del partido de La Plata. Aportes al ordenamiento territorial. Buenos Aires: Consejo Federal de Inversiones, $124 \mathrm{p}$.

JARVIE HP ET AL. 2010. Streamwater phosphorus and nitrogen across a gradient in rural-agricultural land use intensity. Agric Ecosyst Environ 135(4): 238-252.

KARR JR. 1981. Assessment of biotic integrity using fish communities. Fisheries 6(6): 21-27.

KLEIN RD. 1979. Urbanization and stream quality impairment. Water Resour Bull 15(4): 948-963.

KOERBER S, LITZ TO \& MIRANDE JM. 2017. Supplement to Checklist of the Freshwater Fishes of Argentina. Ichthyological Contributions of Peces Criollos 55: 1-11. Available at: http://hdl.handle.net/11336/12893. Accessed on January 2020.

KRAMER AL \& MEHEGAN JP. 1981. Aquatic surface respiration, an adaptive response to hypoxia in the guppy Poecillia reticulate, Pisces Poecilidae. Env Biol Fishes 6(3-4): 299-314.

LENAT DR \& CRAWFORD JK. 1994. Effects of land use on water quality and aquatic biota of three North Carolina Piedmont streams. Hydrobiologia 294(3): 185-99.

LEPŠ J \& ŠMILAUER P. 2003. Multivariate analysis of ecological data using CANOCO. UK: Cambridge University press, $1^{\text {st }}$ ed., $269 \mathrm{p}$.

LEVÊQUE C, OBERDORFF T, PAUGY D, STIASSNY MLJ \& TEDESCO PA. 2008. Global diversity of fish (Pisces) in freshwater. Hydrobiologia 595: 545-567.

LEWIS WM JR. 1970. Morphological adaptations of cyprinodontoids for inhabiting oxygen deficient waters. Copeia 2: 319-326.

LOISELLE SA, CUNHA DGF, SHUPE S, VALIENTE E, ROCHA L, HEASLEY, E, PÉREZ BELMONT P \& AVINOAM B. 2016. Micro and Macroscale Drivers of Nutrient Concentrations in Urban Streams in South, Central and North America. Plos One 11(9): e0162684.

MAGURRAN AE. 1988. Ecological diversity and its measurement. New Jersey: Princeton University Press, $1^{\text {st }}$ ed., $114 \mathrm{p}$.

MENNI R. 2004. Peces y ambientes en la Argentina continental. Monografías del Museo Argentino de Ciencia Naturales. Argentina: Buenos Aires 5: 316.
MIQUELARENAAM \& MENNI RC. 2005. Astyanax tumbayaensis, a new species from northwestern Argentina highlands (Characiformes: Characidae) with a key to the Argentinean species of the genus and comments on their distribution. Rev Suisse de Zool 112(3): 661-676.

MIRANDE JM \& KOERBER S. 2015. Checklist of the Freshwater Fishes of Argentina (CLOFFAR). Ichthyol Contrib Peces Criollos 36: 1-68.

MUGNI HD. 2009. Concentración de nutrientes y toxicidad de pesticidas en aguas superficiales de cuencas rurales. Tesis doctoral. Universidad Nacional de La Plata, 140 p.

MUGNI H, PARACAMPO A \& BONETTO C. 2013. Nutrient Concentrations in a Pampasic First Order Stream with Different Land Uses in the Surrounding Plots (Buenos Aires, Argentina). Bull Environ Contam Toxicol 91(4): 391-395.

OCÓN CS \& RODRIGUES CAPÍTULO A. 2012. Assessment of water quality in temperate-plain streams (Argentina, South America) using a multiple approach. Ecología Austral 22(2): 81-91.

ONORATO D, ANGUS RA \& MARION KR. 2000. Historical changes in the ichthyofaunal assemblages of the upper Cahaba River in Alabama associated with extensive urban development in the watershed. J Freshwater Ecol 15(1): 47-63.

OSBORNE LL \& WILEY MJ. 1988. Empirical relationships between land-use cover and stream water-quality in an agricultural watershed. J Environ Manage 26(1): 9-27.

PADULLES ML, CONFORTI VTD, NANNAVECCHIA P \& O'FARRELL I. 2007. Impacto de la contaminación orgánica sobre el fitoplancton de un arroyo de la llanura pampeana. Ecología Austral 27: 437-448.

PAUL MJ \& MEYER JM. 2001. Streams in the urban landscape. Ann Rev Ecol S 32: 333-365.

PINTO BCT, ARAÚJO FG \& HUGHES RM. 2006. Effects of landscape and riparian condition on a fish index of biotic integrity in a large southeastern Brazil river. Hydrobiología 556(1): 69-83.

PLAUL SE, BARBEITO CG \& díAZ AO. 2016. Histochemical differences along the intestine of Corydoras paleatus (Siluriformes: Callichthyidae). Rev Biol Trop 64: 327-340.

REIS RE, ALBERT JS, DI DARIO F, MINCARONE MM, PETRY P \& ROCHA LA. 2016. Fish biodiversity and conservation in South America. J Fish Biol 89(1): 12-47.

REIS RE \& PEREIRA EH. 2000. Three new species of the loricariid catfish genus Loricariichthys (Teleostei: 
Siluriformes) from southern South America. Copeia 4: 1029-1047.

REMES LENICOV M, COLAUTTI DC \& LOPEZ HL. 2005. Ictiofauna de un ambiente lotico suburbano: El arroyo Rodríguez (Buenos Aires, Argentina). Biol Acuát 22: 223-230.

RIMOLDI F, PELUSO L, BULUS ROSSINI G, RONCO A \& DEMETRIO P. 2018. Multidisciplinary approach to a study of water and bottom sediment quality of streams associated with mixed land uses: Case study Del Gato Stream, La Plata (Argentina). Ecol Indic 89: 188-198.

RINGUELET RA, ARAMBURU RH \& ALONSO DE ARAMBURU AS. 1967. Los peces argentinos de agua dulce. Buenos Aires: Comision de Investigaciones Cientificas, 602 p.

RODRIGUES CAPÍTULO AC, GÓMEZ N, GIORGI A \& FEIJOÓ C. 2010. Global changes in Pampean lowland streams (Argentina): implications for biodiversity and functioning. Hydrobiologia 657: 53-70.

ROSSO J, GONZÁLEZ CASTRO M, BOGAN S, CARDOSO YP, MABRAGAÑA E, DELPIANI M \& DIAZ DE ASTARLOA JM. 2018. Integrative taxonomy reveals a new species of the Hoplias malabaricus species complex (Teleostei: Erythrinidae). Ichthyol Explor Fresh 28(3): 235-252.

SALA OE ET AL. 2000. Global biodiversity scenarios for the year 2100. Science 287(5459): 1770-1774.

SMALE MA \& RABENI CF. 1995. Hypoxia and hyperthermia tolerances of headwater stream fishes. T Am Fish Soc 124(5): 698-710.

SOLARI A, JAUREGUIZAR AJ, MILESSI AC \& GARCÍA ML. 2015. Fish assemblages in a small temperate estuary on the Argentinian coast: spatial variation, environmental influence and relevance as nursery area. Braz J Oceanogr 63(3): 181-194.

STEEDMAN RJ. 1988. Modification and assessment of an index of biotic integrity to quantify stream quality in southern Ontario. Can J Fish Aquat Sci 45(3): 492-501.

TEJERINA-GARRO FL, MALDONADO M, IBAÑEZ C, PONT D, ROSET N \& OBERDORFF T. 2005. Effects of Natural and Anthropogenic Environmental Changes on Riverine Fish Assemblages: a Framework for Ecological Assessment of Rivers. Braz Arch Biol Technol 48(1): 91-108.

TER BRAAK CJF \& SMILAUER P. 1998. CANOCO Reference Manual and User's Guide to Canoco for Windows: Software for Canonical Community Ordination, Version 4. Microcomputer Power, Ithaca, NY, 352 p.

UNITED NATIONS, DEPARTMENT OF ECONOMIC AND SOCIAL AFFAIRS, PUBLICATIONS. 2018. Revision of World Urbanization Prospects. Available at: https://www. un.org/development/desa/publications/2018-revisionof-world-urbanization-prospects.html. Accessed on January 2020.

WALLACE JB, EGGERT SL, MEYER JL \& WEBSTER JR. 1999. Effects of resource limitation on a detrital-based ecosystem. Ecol Monogr 69(4): 409-442.

WANG L, LYONS J, KANEHL P, BANNERMAN R. \& EMMONS E. 2000. Watershed urbanization and changes in fish communities in southeastern wisconsin streams. J Am Water Res Assoc 36(5): 1173-1189.

WANG L, LYONS J, KANEHL P \& GATTI R. 1997. Influences of Watershed Land Use on Habitat Quality and Biotic Integrity in Wisconsin Streams. Fisheries 22(6): 6-12.

WEAVER LA \& GARMAN GC. 1994. Urbanization of a Watershed and Historical Changes in a Stream Fish Assemblage. Trans Am Fish Soc 123(2): 162-172.

YODER CO, MILTNER RJ \& WHITE D. 1999. Assessing the status of aquatic life designated uses in urban and suburban watersheds. In: Proceedings National Conference on Retrofit Opportunities for Water Resource Protection in Urban Environments, p. 16-28.

\section{SUPPLEMENTARY MATERIAL}

Table SI. List of species, abundance and standard length $(\mathrm{cm})$ recorded in pampean streams, Buenos Aires province, Argentina. P: pampean species, R: riverine species.

\section{How to cite}

PARACAMPO A, MARROCHI N, GARCÍA I, MAIZTEGUI T, CARRIQUIRIBORDE P, BONETTO C \& MUGNI H. 2020. Fish Assemblages in Pampean Streams (Buenos Aires, Argentina): Relationship to Abiotic and Anthropic Variables. An Acad Bras Cienc 92: e20190476. DOI. 10.590/00013765202020190476.

Manuscript received on May 24, 2019;

Accepted for publication on August 16, 2019

ARIEL PARACAMPO ${ }^{1}$

https://orcid.org/0000-0001-7651-4989

NATALIA MARROCHI ${ }^{1}$

https://orcid.org/0000-0002-1002-3308

\section{IGNACIO GARCÍA ${ }^{1}$}

https://orcid.org/0000-0002-0454-2603

TOMÁS MAIZTEGUI ${ }^{1}$

https://orcid.org/0000-0002-0224-2041 


\section{PEDRO CARRIQUIRIBORDE ${ }^{2}$}

https://orcid.org/0000-0002-3152-9340

\section{CARLOS BONETTO}

https://orcid.org/0000-0003-0843-1529

\section{HERNÁN MUGNI ${ }^{1}$}

https://orcid.org/0000-0002-8328-7689

${ }^{1}$ Instituto de Limnología Dr. Raúl A. Ringuelet (ILPLA),

CONICET-CCT La Plata-UNLP, Boulevard 120 y 62, №

1437, 1900, La Plata, Buenos Aires, Argentina

${ }^{2}$ Centro de Investigaciones del Medioambiente

(CIM), CONICET, UNLP, Boulevard 120 № 1489,

1900, La Plata Buenos Aires, Argentina

Correspondence to: Ariel Paracampo

E-mail:arielp@ilpla.edu.ar

\section{Author contributions}

AP, HM and CB made substantial contributions to conception, design and acquisition of data, as well as, analysis and interpretation of data and intellectual contribution to manuscript drafting. NM and IG participate actively of the samplings, data acquisition in the field, chemical determinations of nutrients in the laboratory and made contributions to the draft. TM and PC participate in the final edition of the text and reviewed critically the final version of the text adding a relevant intellectual contribution to the draft.

\section{(cc) $\mathbf{B Y}$}

